\title{
PERANCANGAN APLIKASI PENGOLAHAN DATA BUKU PADA PERPUSTAKAAN SMA NEGERI 1 BATANGHARI LAMPUNG TIMUR
}

\author{
Guna Yanti Kemala Sari Siregar ${ }^{(1)}$ Dani Anggoro $^{(2)}$ \\ Prodi S1 Ilmu Komputer, Fakultas Ilmu Komputer \\ Universitas Muhammadiyah Metro
}

Jl. KH. Dewantara No.116 Iring Mulyo Metro, Kota Metro Lampung e-mail: gunayanti2017@gmail.com ${ }^{(1)}$

\begin{abstract}
ABSTRAK
Perpustakaan sekolah merupakan salah satu fasilitas yang disediakan oleh sekolah sebagai pendukung dan penunjang proses kegiatan belajar mengajar bagi para murid. Keberadaan sebuah perpustakaan sangat membantu untuk menambah atau meningkatkan pengetahuan dan wawasan bagi para murid di sekolah. Sistem pengolahan data buku saat ini belum memadai, karena dalam pengolahan data buku pada perpustakaan masih menggunakan buku besar dan sering terjadi kesalahan dalam proses pendataan buku pada perpustakaan, petugas perpustakaan mengalami kesuliatan dalam pembuatan laporan data buku perpustakaan dan memerlukan waktu yang cukup lama untuk dilaporkan kepada kepala sekolah.Penelitian menggunakan metode pengolahan data berupa observasi, interview, dan dokumentasi. Sedangkan perancangan sistem informasi menggunakan Bagan Alir Dokumen, Data Flow Diagram, Entity Relationship Diagram. Software pendukung dalam pembuatan aplikasi pengolahan data buku ini menggunakan Borland Delphi 7 dan database yang digunakan adalah Mysql.Aplikasi pengolahan data buku pada perpusatakaan SMA Negeri 1 Batanghari Lampung Timur menghasilkan rancangan database yaitu dengan database db_buku(1) yang memiliki beberapa tabel yaitu tabel buku, tabel kategori, tabel tambahstok, tabel petugas, serta rancangan antar muka input dan output.Dari Aplikasi ini diharapkan mempermudah dalam mengolah data buku perpustakaan SMA Negeri 1 Batanghari Lampung Timur agar lebih cepat dan terperinci, serta mempermudah dalam pembuatan laporan.
\end{abstract}

Kata Kunci: Perancangan Aplikasi Pengolahan Data Buku Pada Perpustakaan SMA Negeri I Batanghari Lampung Timur, Borland Delphi7, MySQL

\section{PENDAHULUAN}

Seiring perkembangan ilmu pengetahuan dan kemajuan teknologi saat ini semakin berkembang dari tahun-tahun sebelumnya, serta peranan teknologi di berbagai bidang juga sudah semakin penting karena sangat dibutuhkan. Kini instansi-instansi baik swasta maupun pemerintah memanfaatkan fasilitas teknologi dalam pengolahan data yang dulunya diolah secara manual diubah ke dalam pola komputerisasi untuk mempermudah proses pemasukan maupun pencarian data. Perpustakaan sekolah merupakan salah satu fasilitas yang disediakan oleh sekolah sebagai pendukung dan penunjang proses kegiatan belajar mengajar bagi para murid. Keberadaan sebuah perpustakaan sangat membantu untuk menambah atau meningkatkan pengetahuan dan wawasan bagi para murid di sekolah. Dengan adanya perpustakaan, maka pembelajaran akan berlangsung baik, akan didapatkan generasi yang berpestasi dan akan mengahasilkan sekolah yang maju dan berkualitas. SMA Negeri 1 Batanghari Lampung Timur merupakan salah satu Sekolah Menengah Atas Negeri unggulan yang sudah Terakreditasi 


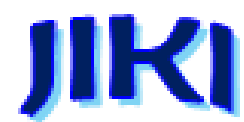

B. Beralamat di Jl.Kapten Harun 47 A Nampirejo Ke. Batanghari Kab. Lampung Timur. SMA Negeri 1 Batanghari berdiri pada tahun 1993, yang disahkan oleh Menteri Pendidikan Nasional yang dipimpin oleh Bapak Wardiman Jojonegoro.SK pendirian sekolah 1993 yang dipimpin oleh Bpk Suripto, S.Pd. Mempuyai guru sebanyak 40 orang, serta mempunyai tenaga kependidikan sebanyak 16 orang, dan 16 kelas X-XII dengan jumlah murid 533 siswa pada TA 2017/2018. sama dengan SMA Negeri pada umumnya di indonesia masa pendidikan sekolah di SMA Negeri 1 Batanghari ditempuh dalam waktu tiga tahun pelajaran, mulai dari Kelas X sampai Kelas XII. Hingga kini sekolah masih merupakan sekolah yang meluluskan lulusan-lulusan yang berpestasi baik bidang akademik maupun non akademik. Gedung semakin baik sebagai fasilitas penunjang pembelajaran dan kini sekolah ini menjadi sekolah yang besar, luas dan hijau. Berdasarkan hasil yang peneliti lakukan di SMA Negeri 1 Batanghari, maka dapat diketahui bahwa jumlah buku yang ada di perpustakaan SMA Negeri 1 Batanghari mempunyai 30.108 buku. Sistem pengolahan data buku saat ini belum memadai, karena dalam pengolahan data buku pada perpustakaan masih menggunakan buku besar dan sering terjadi kesalahan dalam proses pendataan buku pada perpustakaan, petugas perpustakaan mengalami kesuliatan dalam pembuatan laporan data buku perpustakaan dan memerlukan waktu yang cukup lama untuk dilaporkan kepada kepala sekolah.

\section{KAJIAN PUSTAKA DAN LANDASAN TEORI}

\subsection{Aplikasi Berbasis Web}

Untuk membantu teknik penelitian ini, maka digunakan beberapa teori terkait, diantaranya yaitu : Dapat diakses kapan pun dan dari mana pun selama ada internet. Dapat diakses hanya dengan menggunakan web browser (umumnya sudah tersedia di PC,PDA, dan handphone terbaru), tidak perlu menginstall aplikasi client khusus.
Alasan menggunakan aplikasi berbasis web karena Macromedia Dreamwaver MX memasukkan server side development dan memberikan suatu keistimewaan serta kemudahan di dalamnya. Di tambah dengan yang lain yaitu membangun bantuan kemudahan di dalamnya. Ditambah dengan yang lain yaitu membangun bantuan terhadap terhadap PHP dan bantuan yang baik untuk HTML dan CSS.

2.2 PHP (Hypertext Prepcessor)

PHP adalah sebuah bahasa script server side yang dapat digunakan dengan bahasa HTML atau dokumen secara bersamaan untuk membangun sebuah aplikasi web. Bahasa PHP mirip dengan bahasa C Perl, dan java dengan keunikan tersendiri. Sifat open source pada PHP memberikan kemampuan PHP berkembang secara cepat. PHP selain dapat membuat dokumen HTML secara dinamis, dapat membuat gambar, PDF, dan animasi flash dengan script yang sederhana. PHP 8 dapat bekerja dengan baik pada sebagian besar DBMS, diantaranya oracle, MSSQL,SQL server, MySQL, Dbase, PstgreeSQL, dan MySQL.

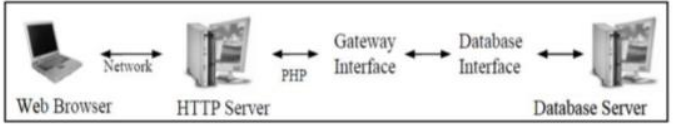

\subsection{Cara Kerja PHP.}

Konsep pemrograman PHP sedikit berbeda dengan pemrograman dengan menggunakan script CGI yang memaksa untuk menulis kode yang menghasilkan keluaran dalam format HTML. Pada PHP, penyisiapan kode ditulis secara bebas setiap ada permintaan terhadap halaman tersebut. Interpreter PHP dalam mengeksekusi script code PHP pada sisi server, dan output dalam bentuk dokumen HTML (Bakken, S., Stig., and Egon, S., 2001). 


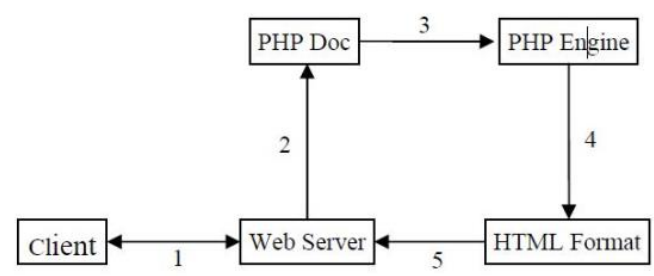

Keterangan gambar :

1. Client melakukan permintaan data ke web server

2. Web server melakukan pengecekan ke skrip php

3. Skrip php diolah di mesin php

4. Skrip php yang berada skrip HTML diekskusi di server

5. Client menerima hasil php di server berupa informasi dalam dokumen HTML

\subsection{Kelebihan PHP}

a. PHP memiliki tingkat akses yang lebih cepat

b. PHP memiliki tingkat lifecycle yang cepat sehingga selalu mengikuti perkembangan teknologi internet.

c. PHP memiliki tingkat kemanan tinggi.

d. PHP mampu berjalan di beberapa server yang ada, misalnya Apache Microsoft IIS, PWS, AOLserver, phttpd dan Xitami.

e. PHP mampu berjalan di linux sebagai platform system operasi utama bagi PHP, namun juga dapat berjalan di FreeBSD,Unix, Solaris,Windosws dan yang lain.

f. PHP juga mendukung akses ke beberapa database yang sudah ada, baik yang bersifat free ataupun komersial. Database itu antara lain MySQL, PostgreSQL, mSQL, Informix, dan MicrosoftSQL server.

g. PHP bersifat free atau gratis.

2.5 Pengertian Borland Delphi Dan Contohnya Delphi adalah sebuah IDE Compiler untuk bahasa pemrograman Pascal dan lingkungan pengembangan perangkat lunak yang digunakan untuk merancang suatu aplikasi program.Delphi juga dapat di artikan sebagai Suatu bahasa pemrograman yang menggunakan visualisasi sama seperti bahasa pemrograman Visual Basic ( VB ). Namun Delphi menggunakan bahasa yang hampir sama dengan pascal (sering disebut objeck pascal). Sehingga lebih mudah untuk digunakan . Bahasa pemrograman Delphidikembangkan oleh CodeGear sebagai divisi pengembangan perangkat lunak milik embarcadero . Divisi tersebut awalnya milik borland, sehingga bahasa ini memiliki versi Borland Delphi .Delphi juga menggunakan konsep yang berorientasi objek ( OOP ) , maksudnya pemrograman dengan membantu sebuah aplikasi yang mendekati keadaan dunia yang sesungguhnya . Hal itu bisa dilakukan dengan cara mendesign objek untuk menyelesaikan masalah . OOP ini memiliki beberapa unsur yaitu ; Encapsulation ( pemodelan ), Inheritance ( Penurunan ), Polymorphism ( Polimorfisme) .Awalnya bahasa pemrograman delphi hanya dapat digunakan di Microsoft Windows, namun saat ini telah dikembangkan sehingga dapat digunakan juga di Linux dan di Microsoft .NET . Dengan menggunakan free pascal yang merupakan proyek OpenSource, bahasa pemrograman ini dapat membuat program di sistem operasi Mac OS X dan Windows CE .Umumnya delphi hanya digunakan untuk pengembangan aplikasi dekstop, enterprise berbasis database dan program -program kecil . Namun karena pengembangan delphi yang semakin pesat dan bersifat general purpose bahasa pemrograman ini mampu digunakan untuk berbagai jenis pengembangan software. Dan Delphi juga disebut sebagai pelopor perkembangan RadTool ( Rapid Apllication Development ) tahun 1995 . Sehinnga banyak orang yang mulai mengenal dan menyukai bahasa pemrograman yang bersifat VCL ( Visual Component Library ) ini . 
2.6 IDE(Integrated Development Environment) adalah program komputer yang memiliki beberapa fasilitas yang diperlukan dalam pembangunan perangkat lunak. Tujuan dari IDE adalah untuk menyediakan semua utilitas yang diperlukan dalam membangun perangkat lunak.Kompilator(Inggris: compiler) adalah sebuah program komputeryang berguna untuk menerjemahkan program komputer yang ditulis dalam bahasa pemrograman tertentu menjadi program yang ditulis dalam bahasa pemrograman lain.Pascaladalah bahasa pemrograman yang pertama kali di buat oleh Profesor Niklaus Wirth, bahasa Pascal ini sebagai alat bantu untuk mengajarkan konsep pemrograman komputer.

\subsection{MySQL}

Adalah DBMS yang open source dengan dua bentuk lisensi, yaitu Free Software (perangkat lunak bebas) dan Shareware (perangkat lunak berpemilik yang penggunaannya terbatas). Jadi MySQL adalah database server yang gratis dengan lisensi GNU General Public License (GPL) sehingga dapat Anda pakai untuk keperluan pribadi atau komersil tanpa harus membayar lisensi yang ada. SQL sendiri merupakan suatu bahasa yang dipakai di dalam pengambilan data pada relational database atau database yang terstruktur. Jadi MySQL adalah database management system yang menggunakan bahasa SQL sebagai bahasa penghubung antara perangkat lunak aplikasi dengan database server. MySQL adalah pengembangan lanjutan dari proyek UNIREG yang dikerjakan oleh Michael Monty Widenius dan TcX (perusahaan perangkat lunak asal Swedia). Sayangnya, UNIREG belum terlalu kompatibel dengan database dinamis yang dipakai di website. TcX kemudian mencari alternatif lain dan menemukan perangkat lunak yang dikembangkan oleh David Hughes, yaitu miniSQL atau mSQL.
Namun, ditemukan masalah lagi karena $\mathrm{mSQL}$ tidak mendukung indexing sehingga belum sesuai dengan kebutuhan TcX. Pada akhirnya muncul kerjasama antara pengembang UNIREG (Michael Monty Widenius), mSQL (David Hughes), dan TcX. Kerjasama ini bertujuan untuk mengembangkan sistem database yang baru, dan pada 1995 dirilislah MySQL seperti yang dikenal saat ini. Saat ini pengembangan MySQL berada di bawah Oracle.

\section{METODE PENELITIAN}

Metode yang dilakukan pada penelitian ini terdiri dari :

3.1 Studi Lapangan

Studi lapangan adalah pengumpulan data dan informasi dari tempatpenelitian, atas masalah yang sedang dihadapi. Adapun studi lapangan yang penulis lakukan adalah dengan teknik :

1) Wawancara (Interview)

Interview adalah metode pengumpulan data dengan cara wawancara atau tanya jawab secara langsung dengan petugas apoteker yang bersangkutan dengan ini penulis melakukan wawancara secara langsung dengan Ibu Sriwidayat Etiningsih. S.Kom selaku Bagian Operator Perpustakaan. (Terlampir tabel wawancara.)

2) Pengamatan (Obsevasi)

Observasi adalah metode pengumpulan data dengan cara pengamatan langsung kegiatan operasional yang berlangsung dii Sma Negeri 1 Batanghari Lampung Timur. Terlampir dokumentasi foto.

3) Dokumentasi (documentation)

Dokumentasi adalah metode pengumpulan data dengan cara mengambil gambar dan mengumpulkan dokumen atau arsip yang dibutuhkan untuk penelitian. Terlampir dokumen-dokumen.

4) Studi Pustaka

Studi pustaka yang penulis lakukan untuk menambahkan beberapa hal yang tidak penulis dapatkan dalam studi lapangan. Dengan cara mengumpulkan data dengan membaca buku- 
buku yang mempelajari literature yang berkaitan dengan masalah yang dihadapi.

\subsection{Waktu dan Tempat Penelitian}

Penulis melakukan penelitian ini dilakukan selama dua bulan yaitu mulai tanggal 01 Maret 2018 sampai dengan 03 Mei 2018, penelitian dilakukan di SMA Negeri 1 Batanghari beralamat di Jl.Kapten Harun 47 A Nampirejo Ke. Batanghari Kab. Lampung Timur.

\subsection{Jadwal penelitian}

Adapun jadwal kegiatan penelitian dapat dilihat pada tabel sebagai berikut:

Tabel: 1.1 .

Jadwal Kegiatan Penelitian

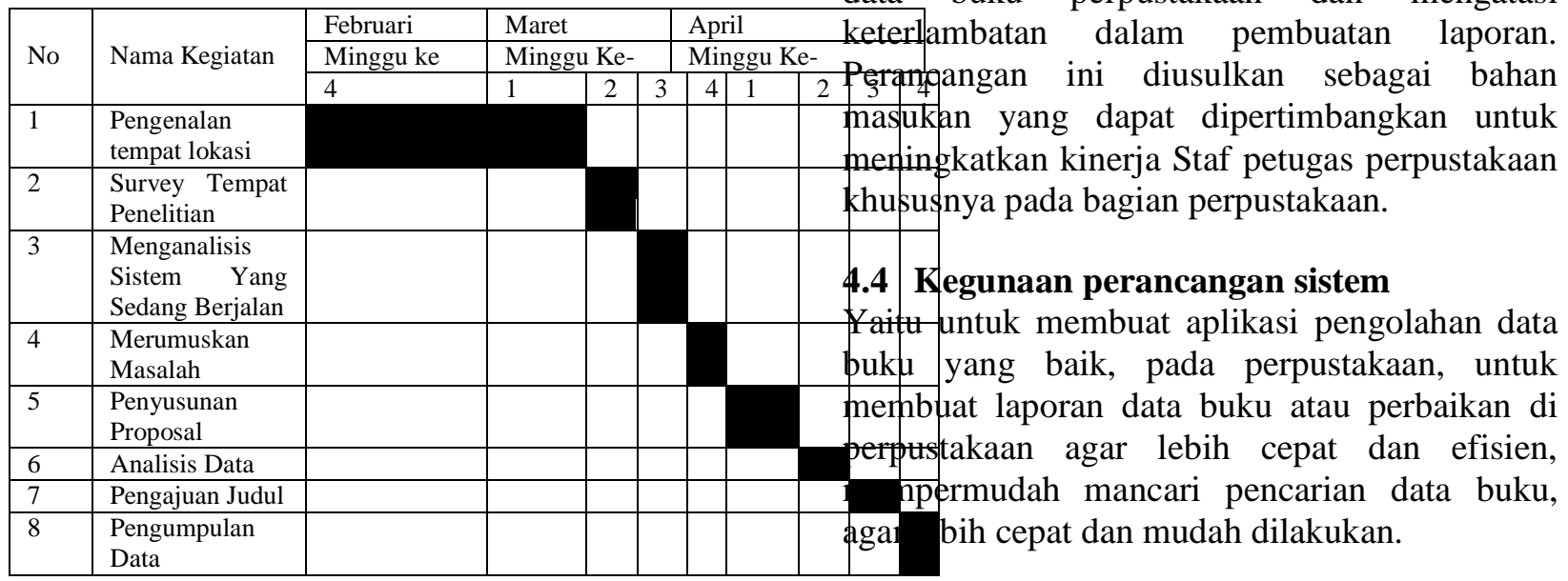

\subsection{Perancangan Aplikasi}

Dalam perancangan suatu program perlu beberapa tahap untuk menentukan arah dari program tersebut. Sama dengan penulis lakukan dalam pembuatan aplikasi ini, di mulai dari pengumpulan data, analisa sistem, menentukan dan membuat alur sistem, membuat relasi tabel, membuat database, merancang tampilan program, sampai pada hasil pembuatan program (output). Berdasarkan analisa sistem di peroleh pengolahan data buku di perpustakaan SMA Negeri 1 Batanghari sebagai berikut :

\subsection{Tujuan Perancangan Sistem}

Tujuan perancangan sistem aplikasi ini, yaitu mengatasi terjadinya kesalahan dalam mengolah data buku perpustakaan dan mengatasi

\subsection{Gambaran Umum Sistem Yang} Diusulkan

\section{HASIL DAN PEMBAHASAN}

\subsection{Hasil Penelitian}

Dari penelitian yang dilaksanakan di perpustakaan SMA Negeri 1 Batanghari Lampung Timur Sistem pengolahan data buku saat ini belum memadai, karena dalam pengolahan data buku pada perpustakaan masih menggunakan buku besar dan sering terjadi kesalahan dalam proses pendataan buku pada perpustakaan, petugas perpustakaan mengalami kesuliatan dalam pembuatan laporan data buku perpustakaan. Akibatnya dari masalah tersebut yaitu keterlambatan dalam memberikan laporan kepada kepala sekolah.
Aplikasi yang diusulkan memiliki beberapa keunggulan dari sistem yang berjalan. Sistem yang diusulkan lebih mudah digunakan. Lebih memperhemat waktu dalam mengolah data buku yang sudah tersimpan di database. Serta mempermudah dalam proses pembuatan laporan.

\subsection{Kebutuhan Sumber Daya}

Besarnya kapasitas penyimpanan dapat dihitung berdasarkan file-file database yang akan menyimpan data untuk priode tertentu.

\subsection{Perangkat Keras (Hardware)}


Rancangan hardware yang diusulkan penulis untuk dipergunakan dalam implementasi sistem yang di rancang adalah :

PCIntel Core i3

Memory (RAM) 4GB

Hard Disk 500GB

Mouse

Keyboard

Printer

\subsection{Perangkat Lunak (Software)}

Pada rancangan ini penulis menggunakan bebrapa perangkat lunak yang mendukung dalam pembuatan aplikasi pengolahan data buku. Adapun spesifikasi prangkat lunak yang digunakan yaitu :

Sistem Operasi Windows 10

Delphi 7

MySQL

QuickReport

\subsection{Rancangan Data Flow Diagram Level 0 ( Nol)}

Data Flow Diagram (DFD) Level 0 pengolahan data buku di perpustakaan SMA Negeri 1 Batanghari.

Rancangan menggambarkan Data Flow Diagram (DFD) data buku perpustakaan di SMA Negeri 1 Batanghari Lampung Timur.

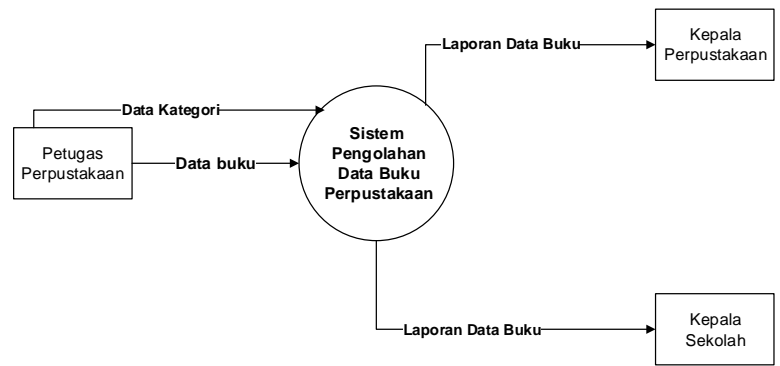

\section{Gambar 4.1}

Rancangan Data Flow Diagram Level 0

(Sumber Penulis Tahun 2018)

\subsection{Rancangan Data Flow Diagram Level 1 (satu)}

Data Flow Diagram (DFD) berikut ini merupakan DFD level 1 perancangan aplikasi pengolahan data buku di perpustakaan SMA Negeri 1 Batanghari Lampung Timur, DFD Level 1 merupakan turunan dari DFD level 0, dapat dilihat pada gambar 4.2 dibawah ini.

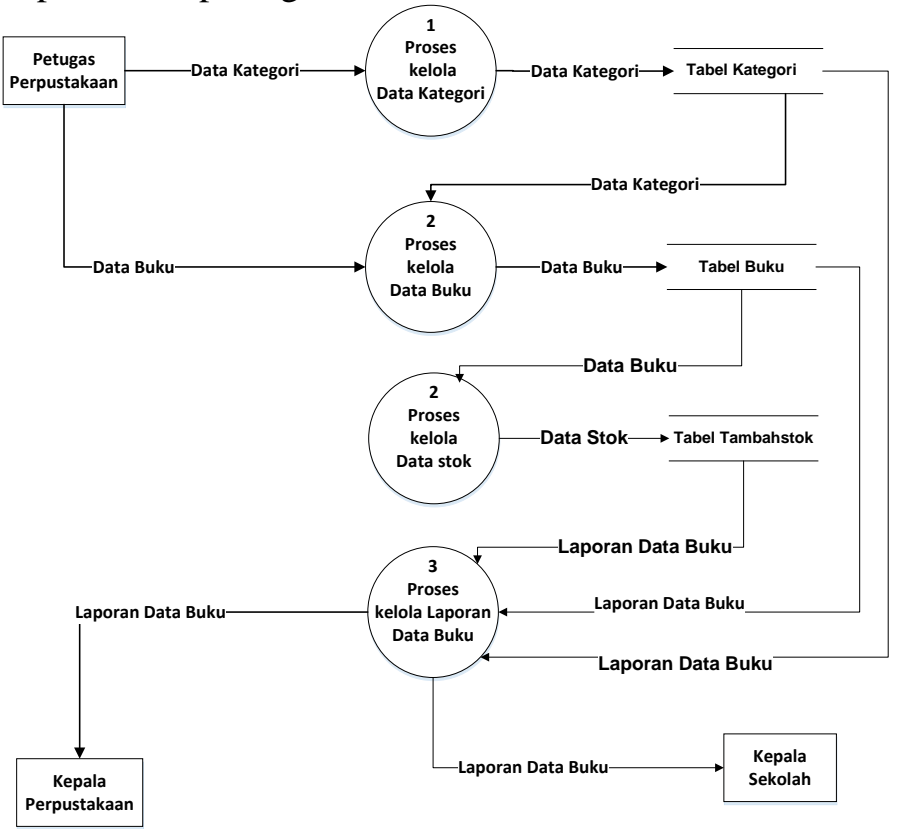

Gambar 4.2

Rancangan Data Flow Diagram Level 1

(Sumber Penulis Tahun 2021)

\section{Bagan Aliran Dokumen}




\section{JIKI}

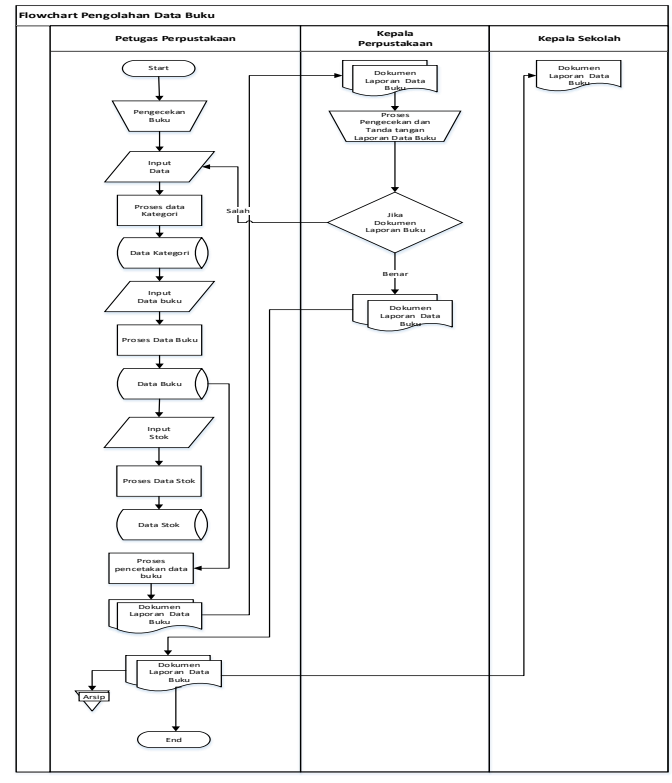

\section{Gambar 4.3}

Bagan Aliran Dokumen

(Sumber Penulis Tahun 2020)

\section{ERD (Entity Relationship Diagram)}

ERD merupakan suatu model untuk menjelaskan hubungan antar data dalam basis data berdasarkan objek-objek dasar data yang mempunyai hubungan antar relasi.

Berikut ini adalah ERD berdasarkan objek-objek dasar pengolahan data buku pada perpustakaan SMA Negeri 1 Batanghari Lampung Timur.

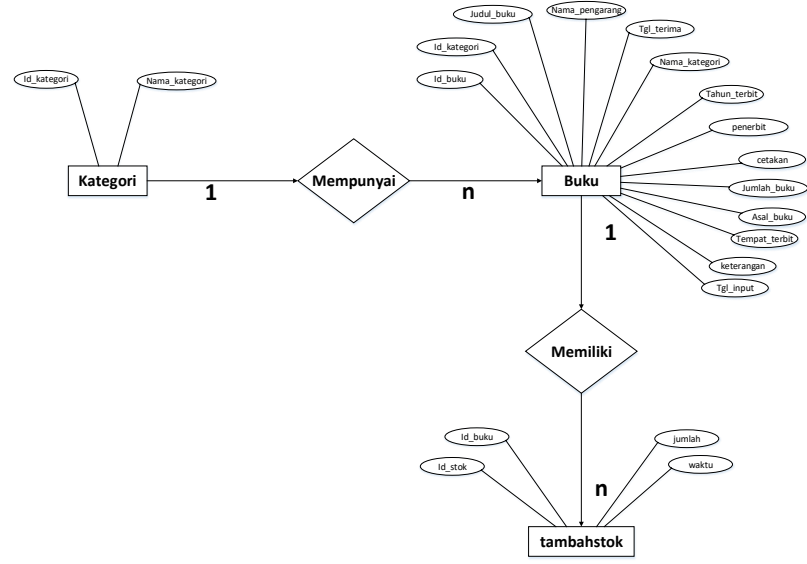

Gambar 4.4

Entity Relationship Diagram (ERD)
(Sumber Penulis Tahun 2020)

\section{Relasi Tabel}

Relasi Tabel adalah hubungan antar tabel yang mempresentasikan antar objek di dunia nyata. Berikut ini adalah Relasi antar table pengolahan data buku pada SMA Negeri 1 Batanghari Lampung Timur.

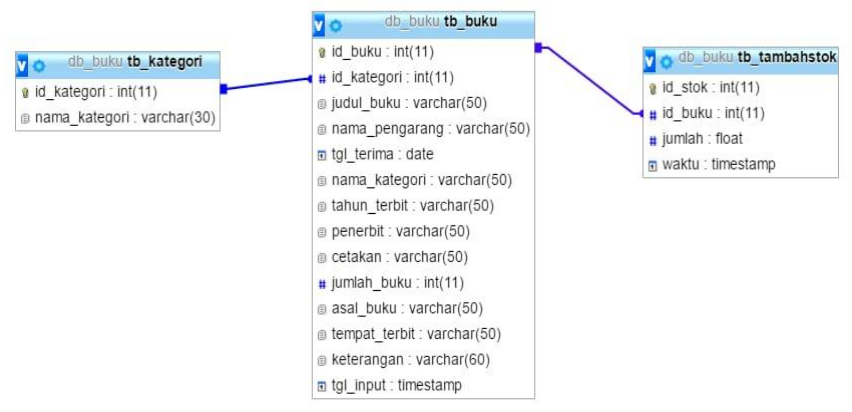

(*) Primary Key : Kunci Utama

(**) Forygen Key : Kunci Tamu

\section{Gambar 4.5}

Relasi Tabel

(Sumber Penulis Tahun 2020)

\section{Rancangan Basis Data}

Basis data adalah mekanisme yang digunkan untuk menyimpan inforamsi atau data.Dengan basis data, pengguna dapat menyimpan data secara terorganisasi.Setelah data disimpan, informasi harus mudah diambil. Cara data di simpan dalam basis data menentukan seberapa mudah mencari informasi berdasarkan banyak kriteria, data pun harus mudah di tambahkan kedalam basis data, dimodifikasi, dan dihapus. Untuk menyimpan data buku pada perpustakaan SMA Negeri 1 Batanghari Lampung Timur di perlukan sebuah database.

Nama Database : db_buku (1) 
Jurnal Ilmu Komputer \& Informatika JKI

Isi Database

tb_buku

Tabel Petugas

Tabel petugas ini berfungsi untuk menyimpan data petugas, berikut ini adalah struktur tabelnya :

Nama tabel

Primary key

: petugas

Jumlah field

: username

$: 2$

\section{Rancangan Sistem}

Sesuai dengan penulis rancang dalam aliran informasi dan diagram arus data (bagian alir dokumen). Berikut adalah program usulan dari bentuk laporan yang harus di sediakan.

\section{$\checkmark$ Rancangan Form Login}

Tampilan ini berfungsi sebagai tempat untuk memasukan username dan password saat akan melakukan input data persediaan obat.

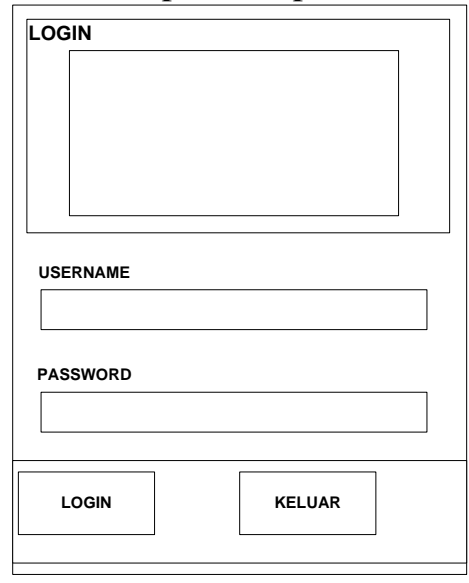

\section{Rancangan Form login}

Pada tampilan menu utama kegunaannya untuk menghubungkan from lainya.

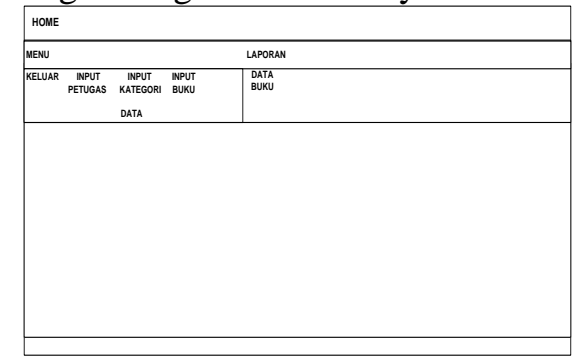

Rancangan Form Menu Utama

\section{Vol.2, No. 1, Juli2021}

Keterangan fungsi-fungsi tombol :

$\sqrt{ }$ Input Petugas : berisi untuk form login petugas bias memasukan username dan password lebih dari 1.

$\sqrt{ }$ Input Kategori : berisi untuk form kategori ,input kategori

$\sqrt{ }$ Input Buku: berisi untuk form buku, untuk input data buku

$\sqrt{ }$ Cetak laporan: untuk form cetak laporan data buku

$\sqrt{ }$ keluar : untuk keluar dari form atau keluar dari program

\section{$\checkmark$ Rancangan Form Input Kategori}

Form kategori digunakan untuk menyimpan kategori, rancangan input kategori

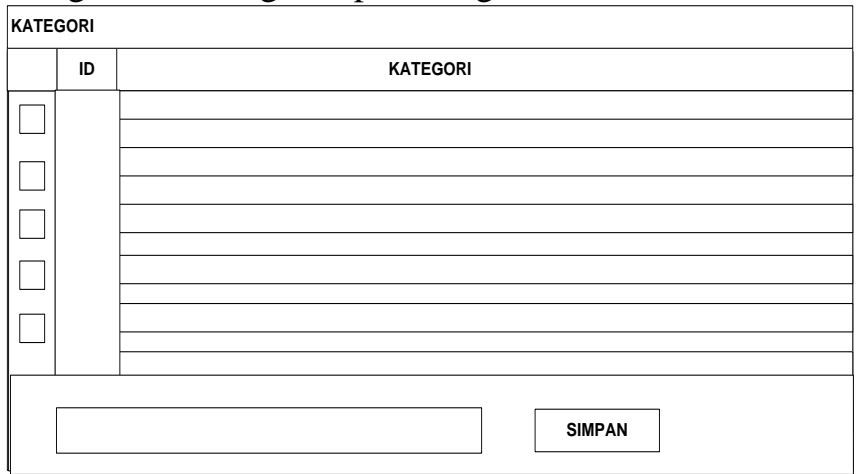

Gambar 4.8.

Rancangan Form Input Kategori

\section{$\checkmark$ Rancangan Form Entry Buku}

Form entry buku digunakan untuk menginput buku. 
Jurnal Ilmu Komputer \& Informatika ॥KI

\begin{tabular}{|l|l|l|}
\hline ENTRY BUKU \\
\hline KATEGORI \\
\hline TENGN TERBIT \\
\hline
\end{tabular}

\section{Gambar 4.9.}

Rancangan Form Entry Buku

Keterangan:

$\sqrt{ }$ Button simpan : digunakan untuk menyimpan hasil inputan

$\sqrt{ }$ Button Rubah : digunakan untuk merubah data yang mau di simpan

$\sqrt{ }$ Button keluar : digunkan untuk keluar dari form entry buku

1. Rancangan Form Daftar Buku

Form daftar buku digunakan untuk mencari data buku yang sudah disimpan.

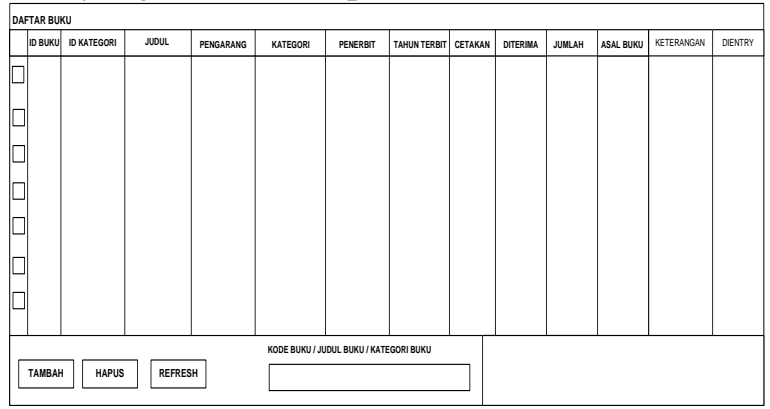

Gambar 4.10.

Rancangan Form Daftar buku

Keterangan:

$\sqrt{ }$ Button Tambah : digunakan untuk menambah data di daftar buku

$\sqrt{ }$ Button Hapus : digunkan untuk menghapus data yang sudah di simpan di daftar buku

\section{Vol.2, No.1, Juli2021}

$\sqrt{ }$ Button Refresh : digunakan untuk merefresh daftar buku

\section{$\checkmark$ Rancangan Form Cetak}

Form cetak digunakan untuk mencetak data buku.

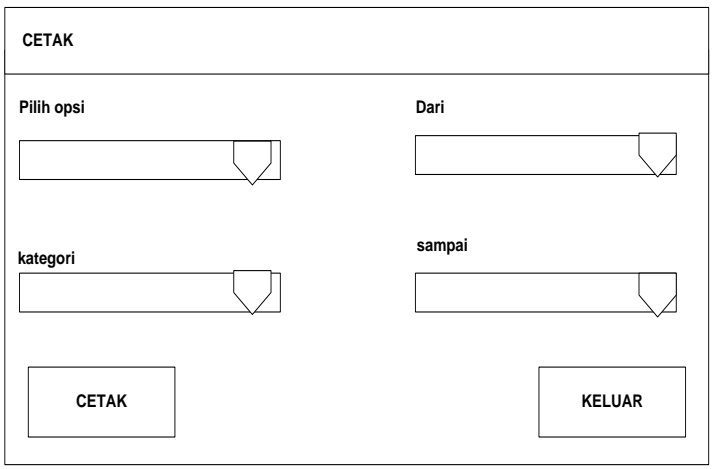

\section{Gambar 4.12.}

Rancangan Form Cetak

Keterangan:

$\sqrt{ }$ Button Cetak : digunakan untuk mencetak data buku

$\sqrt{ }$ Button keluar : digunakan untuk keluar dari form cetak

\section{Rancangan Form Cetak Laporan Data Buku}

Digunakan untuk melaporakan hasil data buku yang sudah di inputkan.

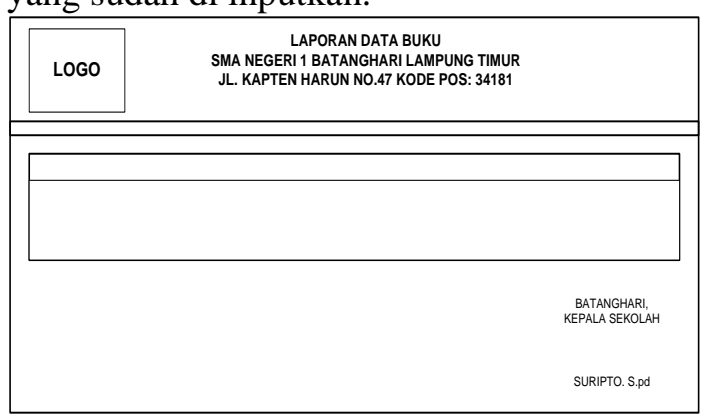

\section{Gambar 4.13.}

Rancangan Cetak Laporan Data Buku

\section{$\checkmark$ Pembahasan Perancangan}

Tampilan Halaman Login

Tampilan login berfungsi untuk hak akses bagi user petugas untuk melihat dan berinteraksi 
JIKI

dengan data serta agar program yang di rancang. seperti pada gambar 4.14 dibawah ini

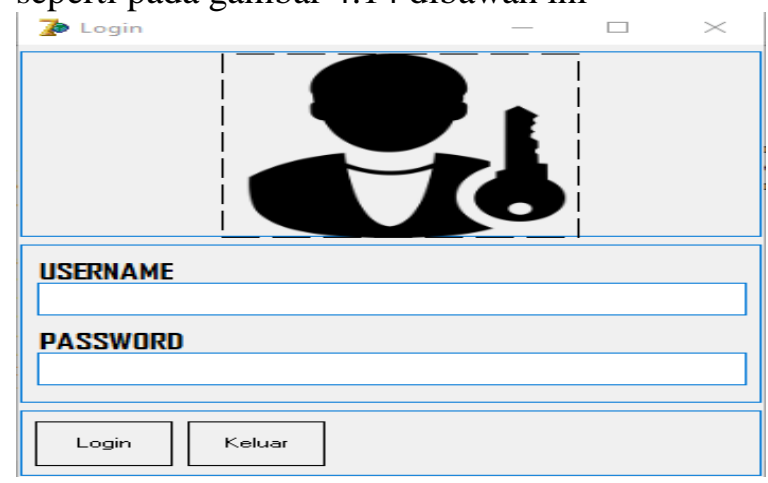

Gambar 4.14. Tampilan Halaman Login

\section{Tampilan Halaman Utama}

Tampilan Halaman Utama berfungsi sebagai tampilan awal Aplikasi Data Buku.

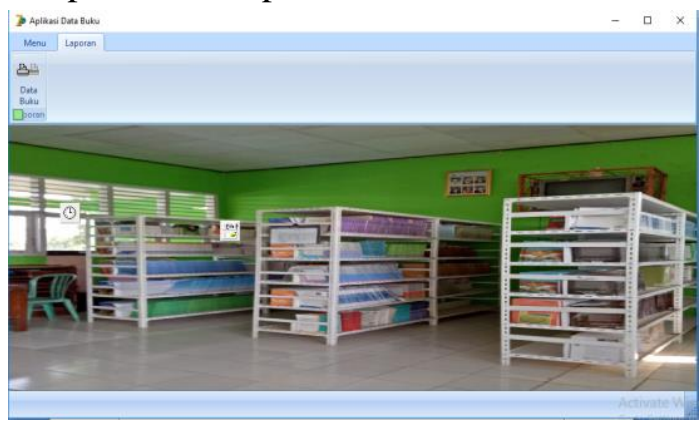

Tampilan Halaman Utama

\section{Tampilan Input Petugas}

Tampilan input petugas berfungsi sebagai memasukan username dan password lebih dari 1 .

\begin{tabular}{l} 
Potugas \\
\hline USERNAME \\
\hline \\
\hline PASSWORD \\
\hline \\
\hline SIMPAN
\end{tabular}

Gambar 4.16.

Tampilan Input Petugas

\section{Tampilan Input kategori}

Tampilan ini berfungsi sebagai tempat untuk memasukan nama kategori buku beserta id kategori.

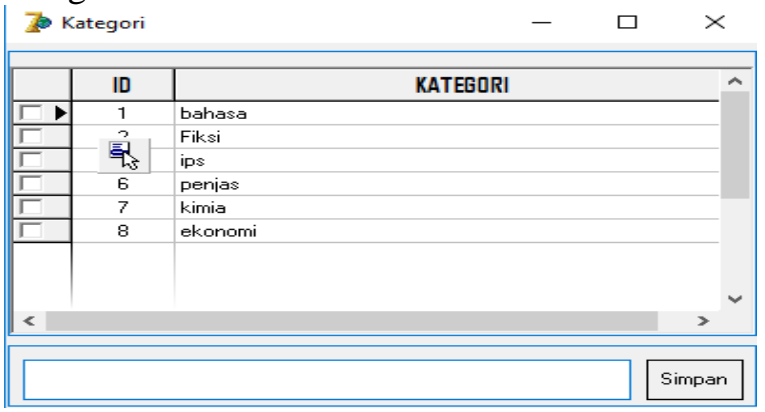

Gambar 4.17.

Tampilan Input Kategori

\section{Tampilan Entry Buku}

Tampilan ini berfungsi sebagai tepat untuk memasukan kategori buku beserta kode buku.

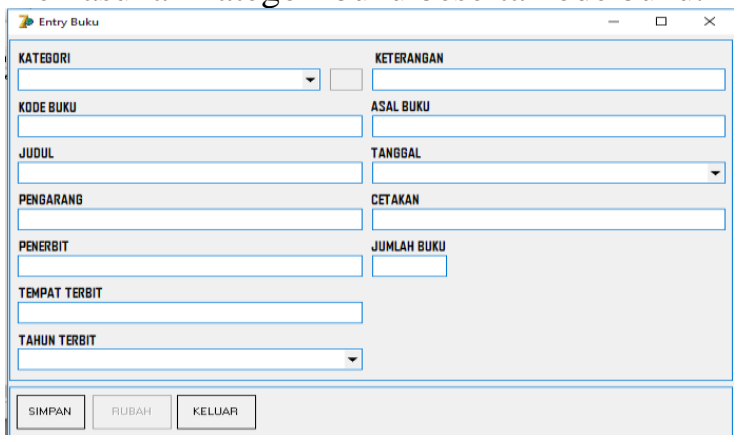

Gambar 4.18

Tampilan Entry Buku

\section{Tampilan Daftar Buku}

Tampilan ini berfungsi sebagai mencari buku dan melihat data buku yang sudah diinputkan. 
Jurnal Ilmu Komputer \& Informatika JIKI

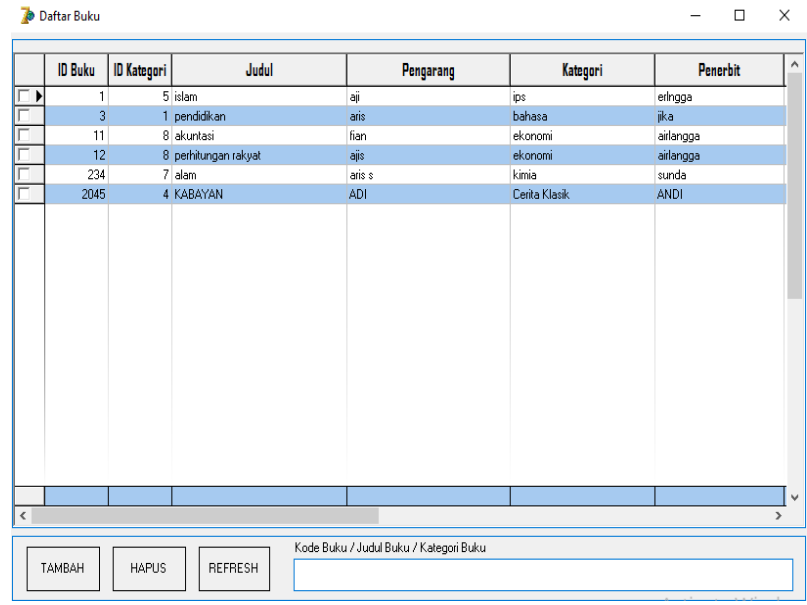

Gambar 4.19

Tampilan Daftar Buku

\section{Tampilan tambah stok}

Tampilan ini berfungsi sebagai menambakan stok buku.

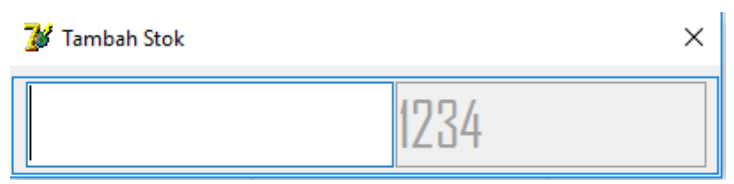

\section{Gambar 4.20}

Tampilan tambah stok

\section{Tampilan cetak}

Tampilan ini berfungsi sebagai mencetak laporan berdasar kan tanggal.

\begin{tabular}{||llll||}
\hline Cetak & - & $\square$ & $\times$ \\
\hline Pilih Opsi & Dari & \\
\hline & & \\
\hline Kategari & Sampai & \\
\hline CETAK & & \\
\hline
\end{tabular}

Gambar 4.21.

Tampilan Cetak

\section{Tampilan Cetak Laporan}

\section{Vol.2, No.1, Juli2021}

Tampilan ini berfungsi sebagai tempat untuk cetak laporan data buku di SMA Negeri 1 Batanghari Lampung Timur.

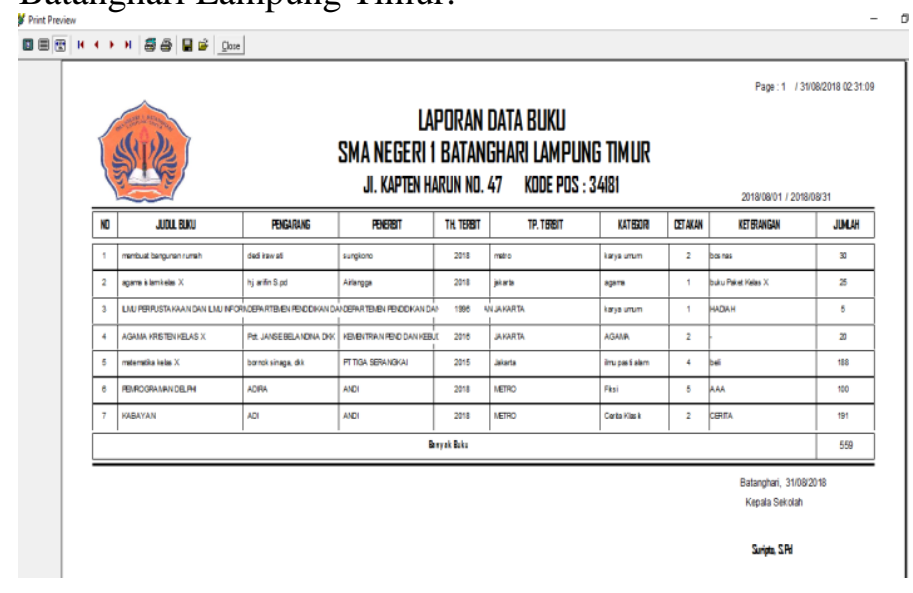

Gambar 4.22

Tampilan Cetak Laporan

\section{Kelebihan Dan Kekurangan Program}

Adapun kelebihan dan kekurangan program yang telah dirancang adalah sebagai berikut :

\section{Kelebihan Program}

Program yang dirancang penulis memiliki beberapa kelebihan yaitu :

Menggunakan aplikasi pengolahan data buku dapat menyimpan data buku, serta dapat mempercepat pencarian data buku.

Mempermudah pembuatan laporan data buku

\section{Kekurangan Program}

Program yang dirancang oleh penulis masih memiliki kekurangan adalah

Aplikasi ini hanya berjalan di sistem operasi berbasis Windows.

Desain pada aplikasi ini masih jauh dari sempurna dan masih memiliki banyak kekurangan.

\section{KESIMPULAN}

Dari hasil penelitian pada Perpustakaan SMA Negeri 1 Batanghari Lampung Timur ndapat diambil kesimpulan yaitu : 
Jurnal Ilmu Komputer \& Informatika JIKI

1. Dalam pembuatan Aplikasi pengolahan data buku ini agar dapat mempermudah petugas dalam pencarian data buku, penulis menggunakan aplikasi pemograman DELPHI 7 dan Database Mysql.

2. Program aplikasi yang penulis buat ini mempermudah petugas dalam pembuatan laporan data buku supaya lebih cepat akurat dan efektif.

\section{DAFTAR PUSTAKA}

Hermansyah Seimbang, Nurhayati 2012, Sistem Informasi Jumlah Angkatan Keria.

Kaputama, ISSN : 1979-6641

Indra Weni, Reni Aryani, Edi Saputra 2018, Sistem Informasi Electronic Medical Record (EMR). Prodi Sistem Informasi, Fakultas Sains dan Ilmu Politik, Universitas Mulawarman. ISSN :18582680

Kani, Firmansyah; Sufandi Unggul Utan 2010, Pemograman Database Menggunkan Delpji (Delphi Win 32 dan MySQL 5.0 dengan Optimalisasi Komponen ZeosDBO), Yogyakarta, Graha Ilmu. ISSN : 978-979-756-680-7

Khairil, Sudarsono Aji 2011, Sistem Informasi Data Kredit Konsumen Reoeat Order, Media Infotama. ISSN : 1858-2680

\section{Vol.2, No.1, Juli2021}

Mahyuni, Sharippudin, Martono 2014, Perancangan Sistem Pengolahan Data Pada SMA Negeri 6 Kabupaten Tebo. Program Studi Teknik Informatika, STIKOM Dinamika Bangsa Jambi. ISSN: 1978-8126

Nani Kurniasih, 2018. Analisis Pengaruh Pelayanan Perpustakaan Terhadap Kepuasan Pengguna Perpustakaan Di Institute Agama Islam Imam Ghozali, Cilacap. ISSN: 2580-8826

Purba Mariana 2017, Perancangan Aplikasi Penjualan. Akademik Manajemen Informatika dan Komputer Lembah Dempo. ISSN : 2301-5632

Puspita Dwi Astuti, 2011, Sistem Informasi Penjualan Obat Pada Apotik Jati Farma Arjosari, Pacitan-Ponorogo. ISSN: 1979-9330

Restiko Wulan Purnomo, 2014. Pembangunan Sistem Informasi Pengolahan Data Pegawai Pada Sekolah Dasar (SD) Negeri Temon 4 Kecamatan Arjosari Pacitan, Pacitan. ISSN: 2302-5700 